\title{
REVIEW
}

\section{SIDEROPHORE: STRUCTURAL AND FUNCTIONAL CHARACTERISATION - A COMPREHENSIVE REVIEW}

\author{
STUTI SAH, RAJNI SINGH*
}

Amity Institute of Microbial biotechnology, Amity University, Uttar Pradesh

SAH, S. - SINGH, R.: Siderophore: structural and functional characterisation - a comprehensive review. Agriculture (Pol'nohospodárstvo), vol. 61, 2015, no. 3, pp. 97-114.

Plants and microbes have enormous importance in our daily life. Iron is said to be the fourth most abundant element in the earth's crust from soil, still many plants face problem in uptaking iron because it is found in insoluble form, which severely restricts the bioavailability of this metal. In response to this, microorganisms present in soil such as Pseudomonas sp., Enterobacter genera, Bacillus and Rhodococcus produce special iron carriers or iron-binding compounds called as 'siderphores' or 'siderochromes'. This paper is an attempt to review the importance of siderphores in enhancing plants' iron utilisation strategies, the mode of transport of siderophores along with iron across the memberane and depending on the difference in their chemical structure, functional moiety and their source of isolation of four different types of siderophore (hydroxamates, catecholates, carboxylates and siderophore with mixed ligand). Siderophore and their derivative have large application in agriculture as to increase soil fertility and as biocontrol for fungal pathogen. This review unlike other reviews includes (1) types of siderophore, (2) the structural difference amongst them, (3) siderophore biosynthesis, (4) transport mechanism, (5) the genetics of siderophore and (6) their efficacy in human life.

Key words: siderophore, phytosiderophore, catecholate siderophore, hydroxamate siderophores, carboxylate siderophore, transport of iron, rhizosphere bacteria

Siderophores are compounds from ancient Greek words, sidero 'iron' and phore 'carriers' meaning 'iron carriers'. These are low-molecular-weight $(<10 \mathrm{kDa})$ iron-chelating compounds, produced by 'rhizospheric bacteria' under iron-limited conditions in order to enhance the plant growth by scavenging iron from the environment and making the mineral available to the cell near the root (Neilands 1952; Lankford 1973; Alexander \& Zubererm 1991; Hider \& Kong 2010; Maheshwari 2011; Ahmed \& Holmstrom 2014). Iron is the major component for various vital functions (photosynthesis, enzyme cofactor, redox reagent, respiration, synthesis of nucleosides and amino acids) of the plant. Owing to deficiency of iron, various plants seem to rely on excretion of phytosiderophore (i.e. chelate compounds, common in grasses that sequester iron) by the roots and secretion of siderophore by group of microbes to facilitate the Fe complex uptake under iron deficiency conditions, which binds with high affinity for iron (Takagi 1976; Mino et al. 1983; Marschner et al. 1986; Neilands 1995; Kannahi \& Senbagam 2014). It has been assumed that competition for iron in the rhizosphere is controlled by the empathy of the siderophores for iron (Loper \& Henkels 1999; Bernd \& Rehm 2008; Munees \& Mulugeta 2014). Siderophores function as plant growth promoters (Yadav et al. 2011; Verma et al. 2011), biocontrol agents (Verma et al. 2011) and bioremediation agents (Wang et al. 2011; Ishimaru et al.

Prof. (Dr.) Rajni Singh (Additional Director) (*Corresponding author), Amity Institute of Microbial Biotechnology, Amity University, Sector 125, Noida,UP, India. E-mail: rsingh3@amity.edu; rajni_vishal@yahoo.com 
2012), in addition to their valuable role in soil mineral weathering (Reichard et al. 2005; Buss et al. 2007; Shirvani \& Nourbakhsh 2010). Alkaline soils are considered to be the potential inducers of iron deficiency in plants in spite of the presence of iron in high concentration in the soil, when the soil $\mathrm{pH}$ exceeds $6.5-7.0$, the availability of iron in the soil is significantly reduced, whilst calcareous soils, which have high $\mathrm{pH}$, decrease the affinity of plants for $\mathrm{Fe}$ and thus impede Fe uptake mechanism.

\section{Classification of Siderphores}

A great variation is seen in siderophore structure produced by many bacteria. Siderophores are generally classified on the basis of co-ordinating groups that chelate the Fe (III) ion. The most common co-ordinating groups are catecholates, hydroxamates and carboxylates (Ali \& Vidhale 2013). A minority of siderophores have chemically distinct Fe (III) ion binding group, including salicylic acid, oxazoline or thizoline nitrogen. Some siderophores including pyoverdines are classified as 'mixed ligands' having co-ordinating groups that fall into chemically different classes (Table 1). Different types of siderophore were identified by electrophoretic mobility, spectrophotometric titration, proton nuclear magnetic resonance spectroscopy, mass spectrometry, acid hydrolysis and biological activity.

\section{Catecholate - siderophore}

Siderophore exhibiting phenolate or 2,3-dihydroxy benzoate (DHB) binding groups belong to the catecholate type of siderophore. Catechol, also known as pyrocatechol or 1,2-dihydroxybenzene, is an organic compound with the molecular formula $\mathrm{C}_{6} \mathrm{H}_{4}(\mathrm{OH})_{2}$. It is the orthoisomer of the three isomeric benzenediols. This colourless compound occurs naturally in trace amounts. In iron-limited medium, Azotobacter vinelandii produces three catecholate siderophores, namely, tricatecholate protochelin, the dicatecholate azotochelin and the monocatecholate aminochelin (Corbin \& Bulen 1969; Page \& Tigerstrom 1988; Cornish \& Page 1995; Wittmann et al. 2001).

\subsection{Enterobactin}

This catecholate-type siderophore is a cyclic trimer composed of 2,3-dihydroxy- $N$-benzoylserine. Three molecules of the DHB-Ser formed under- go intermolecular cyclisation, yielding enterobactin. Enterobactin was the first tricatechol siderophore, isolated from Escherichia coli, Aerobacter aerogenes and Salmonella typhimurium (Ward et al. 1999). Enterobactin (Enterochelin) are produced by bacteria of the family Enterobacteriaceae, includes all strains of $E$. coli having high affinity for iron. S. typhimurium, Klebsiella pneumoniae and Erwinia herbicola are also known to produce enterobactin. Enterobactin is the strongest siderophore having the capacity to chelate iron even from the environment where concentration of iron is very low (Raymond et al. 2003). E. coli enterobactin has a molecular weight of $669 \mathrm{kDa}$, which exceeds the size limit for diffusion across the outer membrane. Therefore, enterobactin are synthesised with the help of active transport mechanism for transport and capturing iron (Hans et al. 2001; Gregory et al. 2012). In the year 1998, Cornish and Page observed that the catecholate siderophores were hyper-produced to offer chemical protection from oxidative damage catalysed by $\mathrm{O}_{2}$ and $\mathrm{Fe}$.

\section{Hydroxamate-type siderophores}

Ferrichrome-type hydroxamate siderophores are of special ecological interest because of their production by many soil fungi (Zahneret et al. 1963; O'Sulivan \& O'Gara 1992; Schalk et al. 2011), including symbiotic ectomycorrhizal fungi, and their ability to mobilise iron in neutral and alkaline soils in which other naturally occurring compounds are ineffective as iron chelators because of competition from other metal ions (Cline et al. 1982). Experimental evidence indicates that hydroxamate siderophores can supply iron to some plant species. Hydroxamate siderophores are generally produced by fungi and belong to Zygomycotina (Mucorales), Ascomycotina (Aspergilli, Penicillia, Neurosporacrassa) and Deuteromycotina (Fusarium dimerum). Hydroxamate siderophores were mostly trihydroxamates, followed by dihydroxamates. Monohydroxamate nature was not shown by any of the reported fungal siderophores. Hydroxamate siderophores formed hexadentate, tetradentates and bidentate ligands. A good correlation was observed between hydroxamate groups and ligand property. Ferrichrome belonging to hydroxamate are either linear or crystal in structure. Certain ferrichrome deriva- 


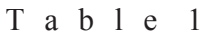

Structural, chemical and functional moiety of major bacterial siderophore

\begin{tabular}{|c|c|c|c|c|c|c|}
\hline & $\begin{array}{l}\text { Type of Side- } \\
\text { rophore }\end{array}$ & Structure & $\begin{array}{l}\text { Chemical } \\
\text { moiety }\end{array}$ & Function & $\begin{array}{l}\text { Bacterial } \\
\text { source }\end{array}$ & Reference \\
\hline 1 & \multicolumn{6}{|c|}{ Catecholate: phenolate or 2,3-dihydroxy benzoate (DHB) binding groups } \\
\hline & (a) Enterobactin & & $\begin{array}{l}\text { 2,3-dihydroxy } \\
-N \text {-benzoylse- } \\
\text { rine a cyclic } \\
\text { trimer }\end{array}$ & $\begin{array}{l}\text { Iron-chelating } \\
\text { compound } \\
\text { and used in } \\
\text { agriculture }\end{array}$ & $\begin{array}{l}\text { Family Ente- } \\
\text { robacteriaceae, } \\
\text { e.g. E. coli }\end{array}$ & $\begin{array}{l}\text { Pollack \& Neilands } \\
\text { 1970; } \\
\text { Walsh et al. 1990; } \\
\text { O'Brien et al. 1970; } \\
\text { Gregory et al. 2012; } \\
\text { IUPAC, Commis- } \\
\text { sion on Nomen- } \\
\text { clature of Organic } \\
\text { Chemistry, } 1993\end{array}$ \\
\hline \multirow[t]{4}{*}{2} & \multicolumn{6}{|c|}{ Hydroxamate: esters or acid chlorides or carboxylic acids } \\
\hline & $\begin{array}{l}\text { (a) Aferrioxa- } \\
\text { mines }\end{array}$ & & $\begin{array}{l}\text { Linear trihyd- } \\
\text { roxamates }\end{array}$ & $\begin{array}{l}\text { Used medically } \\
\text { for the binding } \\
\text { of excess blood } \\
\text { iron in the } \\
\text { treatment of } \\
\text { thalsaemia }\end{array}$ & $\begin{array}{l}\text { Streptomyces } \\
\text { and Nocardia }\end{array}$ & $\begin{array}{l}\text { O'Brien et al. } 1970 \text {; } \\
\text { Gregory et al. 2012; } \\
\text { IUPAC, Commis- } \\
\text { sion on Nomen- } \\
\text { clature of Organic } \\
\text { Chemistry, } 1993\end{array}$ \\
\hline & (b) Ferrichrome & & $\begin{array}{l}\text { Cyclic trihyd- } \\
\text { roxamate }\end{array}$ & $\begin{array}{l}\text { Growth factor } \\
\text { for other mic- } \\
\text { robes }\end{array}$ & $\begin{array}{l}\text { Basidomyce- } \\
\text { tes producing } \\
\text { fungal species, } \\
\text { e.g. Ustilagos- } \\
\text { phaerogena }\end{array}$ & $\begin{array}{l}\text { Jalal \& van der } \\
\text { Helm 1991; O'Brien } \\
\text { et al. 1970; Gregory } \\
\text { et al. 2012; IUPAC, } \\
\text { Commission on } \\
\text { Nomenclature of } \\
\text { Organic Chemistry, } \\
1993\end{array}$ \\
\hline & (c) Aerobactin & & $\begin{array}{l}\text { A trihydroxy- } \\
\text { tetraoxo tetra } \\
\text { azatricosane-tri- } \\
\text { carboxylic acid }\end{array}$ & $\begin{array}{l}\text { Sequester iron } \\
\text { in iron-poor } \\
\text { environments } \\
\text { such as the } \\
\text { urinary tract }\end{array}$ & $\begin{array}{l}\text { Pseudomonas } \\
\text { of marine ori- } \\
\text { gin, Klebisella } \\
\text { pneumonia, } \\
\text { Aerobacterae- } \\
\text { rogenes }\end{array}$ & $\begin{array}{l}\text { Buyer et al. 1991; } \\
\text { Meyrier 1999; } \\
\text { O'Brien et al. 1970; } \\
\text { Gregory et al. 2012; } \\
\text { IUPAC, Commis- } \\
\text { sion on Nomen- } \\
\text { clature of Organic } \\
\text { Chemistry, } 1993\end{array}$ \\
\hline \multirow[t]{2}{*}{3} & \multicolumn{6}{|c|}{ Carboxylate: hydroxyl carboxylate and carboxylates } \\
\hline & Rhizoferrin & & $\begin{array}{l}\text { Diaminopropa- } \\
\text { neacylated with } \\
\text { citric acid via } \\
\text { amine bonds } \\
\text { to the terminal } \\
\text { carboxylate of } \\
\text { citric acid }\end{array}$ & $\begin{array}{l}\text { Application in } \\
\text { biotechnology: } \\
\text { metal-binding } \\
\text { properties and } \\
\text { the ability to be } \\
\text { easily degra- } \\
\text { ded by various } \\
\text { microorganism }\end{array}$ & $\begin{array}{l}\text { Fungi, specifi- } \\
\text { cally mem- } \\
\text { bers of the } \\
\text { zygomycetes }\end{array}$ & $\begin{array}{l}\text { Winkelmann 1991; } \\
\text { Stephan et al. 1996; } \\
\text { O'Brien et al. 1970; } \\
\text { Gregory et al. 2012; } \\
\text { IUPAC, Commis- } \\
\text { sion on Nomen- } \\
\text { clature of Organic } \\
\text { Chemistry, } 1993\end{array}$ \\
\hline
\end{tabular}


Table 1 continued

\begin{tabular}{|c|c|c|c|c|c|c|}
\hline & $\begin{array}{l}\text { Type of Side- } \\
\text { rophore }\end{array}$ & Structure & $\begin{array}{l}\text { Chemical } \\
\text { moiety }\end{array}$ & Function & $\begin{array}{l}\text { Bacterial } \\
\text { source }\end{array}$ & Reference \\
\hline & \multicolumn{6}{|c|}{ Siderophore with mixed ligand } \\
\hline 1 & \multicolumn{6}{|c|}{ Lysine derivative } \\
\hline & Myobactin & B & $\begin{array}{l}\text { Two structural } \\
\text { classes based } \\
\text { on the presence } \\
\text { or absence of a } \\
\text { 2-hydroxyphe- } \\
\text { nyloxazoline } \\
\text { ring system }\end{array}$ & $\begin{array}{l}\text { Chemotaxano- } \\
\text { mic markers for } \\
\text { identification of } \\
\text { mycobacteria } \\
\text { upto species } \\
\text { level }\end{array}$ & $\begin{array}{l}\text { M. tuber- } \\
\text { culosis, } M \text {. } \\
\text { smegmatis }\end{array}$ & $\begin{array}{l}\text { Stephen et al. } \\
\text { 1998; De Voss et } \\
\text { al. 1999; Varma \& } \\
\text { Podila 2005 }\end{array}$ \\
\hline 2 & \multicolumn{6}{|c|}{ Ornithine derivative } \\
\hline & Pyoverdine & & $\begin{array}{l}\text { Chromophore, } \\
\text { (1S)-5-ami- } \\
\text { no-2,3-dihyd- } \\
\text { ro- } 8,9 \text {-dihyd- } \\
\text { roxy-1H-py- } \\
\text { rimido[1,2-a] } \\
\text { quinoline-1-car- } \\
\text { boxylic acid }\end{array}$ & $\begin{array}{l}\text { Prevention of } \\
\text { iron overload } \\
\text { toxicity } \\
\text { Inhibition of } \\
\text { pathogenic } \\
\text { bacterial growth }\end{array}$ & $\begin{array}{l}\text { Pseudomonas } \\
\text { aeruginosa }\end{array}$ & $\begin{array}{l}\text { Wendenbaum et al. } \\
\text { 1983; Lamont \& } \\
\text { Martin 2003; Meyer } \\
2000\end{array}$ \\
\hline 3 & \multicolumn{6}{|c|}{ Histamine derivative } \\
\hline & Anguibactin & & $\begin{array}{l}\omega-\mathrm{N}-\mathrm{hyd}- \\
\text { roxy- } \omega-\left[\left[2^{\prime}\right.\right. \\
-\left(2^{\prime \prime}, 3 !-\mathrm{dihyd}-\right. \\
\text { roxyphenyl) } \\
\text { thiazolin-4' } \\
\text {-yl]-carboxy] } \\
\text { histamine }\end{array}$ & $\begin{array}{l}\text { Inhibits iron } \\
\text { uptake by } \\
\text { living cells, } \\
\text { removes iron } \\
\text { from other } \\
\text { siderophores } \\
\text { and ferric } \\
\text { hydroxide, } \\
\text { aqueous soluti- } \\
\text { ons, including } \\
\text { cell-culture } \\
\text { media }\end{array}$ & $\begin{array}{l}\text { Vibrio angu- } \\
\text { illarum }\end{array}$ & Jalal et al. 1989 \\
\hline
\end{tabular}

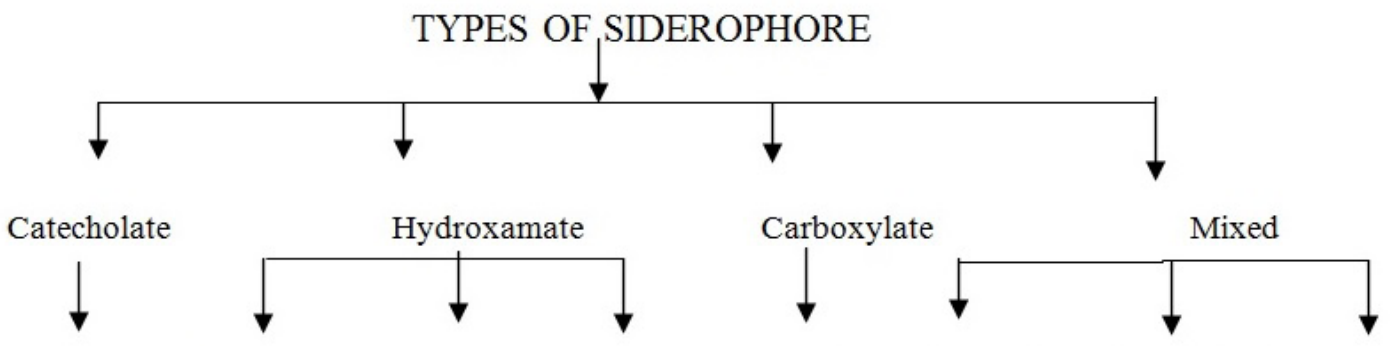

Enterobactin a)Aferrioxaminesb) Ferrichrom c)Aerobactin Rhizoferrin a)Lysine b)Ornithine c)Histamine

derivative derivative derivative

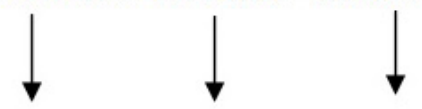

Myobactin Pyoverdine Anguibactin 
tives (ferrioxamines) display antibiotic activity and have been designated as ferrimycines (Bickel 1960). Hydroxamate siderophore family include rhodotorulic acid, dimerium acid, alcaligens and putribactin.

\subsection{Aferrioxamines}

These are linear trihydroxamates siderophores with a molecular formula of $\mathrm{C}_{25} \mathrm{H}_{48} \mathrm{~N}_{6} \mathrm{O}$, produced by Streptomyces and Nocardia. These are used therapeutically for the binding of excess blood iron in the treatment of thalsaemia. It is on the World Health Organization's List of Essential Medicines, a list of the most important medication needed in a basic health system WHO Model List of Essential Medicines (World Health Organization 2013).

\subsection{Ferrichrome}

The ferrichromes comprise one large family of hydroxamate siderophores. These are cyclic trihydroxamate siderophore. Ferrichromes are cyclic hexapeptide siderophores composed of three $N$-acyl- $N$-hydroxyl-L-ornithine, two variable amino acids (alanine, serine, or glycine), and a glycine linked by way of peptide bonds. Five acyl groups at may be acetyl, malonyl, trans- $\beta$-methylglutaconyl, trans-anhydromevalonyl and cis-anhydromevalonyl. The acyl groups are homogeneous in each ferrichrome produced by Basidomycetes, except for the asperchromes, which are synthesized by Aspergillus ochraceous (Jalal \& Van der Helm 1991; Renshaw et al. 2002; Ali et al. 2011). Ferrichrome produced by the fungus Ustilago sphaerogena was the first siderophore to be isolated and shown to be a growth factor for other microbes (Neilands 1981).

\subsection{Aerobactin}

Aerobactin is a bacterial iron-chelating agent (siderophore) found in E. coli with a molecular formula of $\mathrm{C}_{22} \mathrm{H}_{36} \mathrm{~N}_{4} \mathrm{O}_{13}$ (Neilands 1995; Johnson et al. 1988). This hydroxamate siderophore is an exogeneous siderophore of Pseudomonas (marine origin), K. pneumonia, A. aerogenes, E. coli and other bacteria (Buyer et al. 1991). It is a virulence factor enabling $E$. coli to sequester ironin iron-poor environments. Under iron-limiting conditions, the Pseudomonas sp. produced aerobactin, a dihydroxamate siderophore previously found only in the family Enterobacteriaceae.

\section{Carboxylate-type siderophore - Rhizoferrin}

This is a novel class of siderophore whose members neither possess hydroxamate nor phenolate ligands rather iron binding is achieved by hydroxyl carboxylate and carboxylates (Schwyn \& Neiland 1987). Rhizoferrin is composed of diaminopropane symmetrically acylated with citric acid via amine bonds to the terminal carboxylate of citric acid (Drechsel et al. 1992). These siderophore are found in the kingdom of bacteria as well in the realm of fungi. Rhizoferrin is the only known carboxylate siderophore produced by fungi, specifically synthesised by members of the zygomycetes. Carboxylate siderophore include Rhizobacteria, Staphyloferrin and Rhizopherrin (Stephan et al. 1996). Interestingly, both fungi and bacteria produce rhizoferrin, fungi produce only $R, R$-rhizoferrin, whilst a few bacteria produce enantio-rhizoferrin $S, S$-rhizoferrin (Munzinger et al. 1999).

\section{Siderophore with mixed ligand}

Apart from above siderophores, certain siderophores have the mixed ligands of lysine, ornithine and histamine derivatives.

\subsection{Lysine Derivative}

\subsubsection{Myobactin}

Mycobactins are 2-hydroxy phenyl oxazoline containing siderophore molecules for the acquisition of iron. Two chemical structures of siderophores produced by Mycobacterium tuberculosis are reported, one of the structure being more lipophilic in nature, whereas the other structure is more hydrophilic. The only chemical difference between the two is the nature of the $\mathrm{N}$-acyl chain on the hydroxylated lysine in the middle of the molecule. Myobactin siderophore isolated from Myobacteria revealed that in mycobactin, two hydroxamate, a phenolate and a oxazoline nitrogen, were present. M. tuberculosis produces only the mycobactin class of siderophore molecule, which contains this salicylic-acid-derived moiety. Saprophytic mycobacteria such as Mycobacterium smegmatis produce both this and a peptidic siderophore, called as exochelin (De Voss et al. 1999; Varma \& Podila 2005). 


\subsection{Ornithine derivative}

\subsubsection{Pyoverdines}

Pyoverdine/pseudobactins contain a dihydroxyquinoline derivative. The structure of the peptide differs between pseudomonads and more than 40 structures have been described, whilst the chromophore, (1S)-5-amino-2,3-dihydro-8,9-dihydroxy-1H-pyrimido [1,2-a]quinoline-1 carboxylic acid, is the same with the exception of azobactin from A. vinelandii, which possesses an extra urea. The chromophore derived from 2,3-diamino-6,7-dihydroxyquinoline are linked to a peptide chain exhibiting two hydroxamate groups or one hydroxamate and one hydroxycarboxylate group. A variety of fluorescent chromopeptide siderophore termed pseudobactin and pyoverdines are synthesised by Pseudomonas species. Pseudomonas spp. are of considerable importance both in agriculture and as human pathogens (Kloepper et al. 1980). Two important siderophore-mediated iron uptake systems have been found in these bacteria: one involving the fluorescent siderophore pseudobactin (also known as pyoverdin) and the other involving the siderophore pyochelin (Abddalah 1991; Meyer 2000; Meneely \& Lamb 2007).

\subsection{Histamine derivative}

\subsubsection{Anguibactin}

The chemical structure of anguibactin has been identified as $\omega$ - $N$-hydroxy- $\omega$-[ [ $2^{\prime}-\left(2^{\prime \prime}, 3^{\prime \prime}\right.$-dihydroxyphenyl)thiazolin-4'-yl]-carboxy]histamine, isolated from marine pathogen Vibrio anguillarum (Jalal et al. 1989). Anguibactin acts as an inhibitor for uptake of iron by living cells, wrests iron from vertebrate tissues, removes iron from other siderophores and ferric hydroxide and removes ferric ion from aqueous solutions, including cell culture media.

\section{Pathways for siderophore biosynthesis}

There are two major pathways for siderophore biosynthesis:

A. Non-ribosomal peptide synthetases (NRPSs) multienzymes dependant.

\section{B. NRPS independent.}

NRPSs are large, multimodular enzymes that perform non-ribosomal peptide (NRP) synthesis in which each module is responsible for the incorporation of one amino acid into the peptide chain.
The number and order of the modules usually dictate the number and order of amino acids in the peptide product (Crosa \& Walsh 2002). The activation (A)-domain of each module of the NRPS recognises and activates a specific amino acid as its acyl adenylate by reaction with ATP. This activated ester is then covalently linked as its thio-ester on the thiolation $(\mathrm{T})$ domain. The condensation (C) domain catalyses the direct transfer to another acyl amino acid intermediate on the adjacent downstream module to form a peptide bond (Ravell \& Cornelis 2003). NRPSs synthesises both the chromophores (Mossialos et al. 2002 ) and the peptide chains of pyoverdine (Crosa \& Walsh 2002).

\section{(A) NRPS-dependent biosynthesis}

The enzyme involved in the synthesis is ATP pyrophosphate, which is widely used in exchange assay and to investigate the substrate specificity of adenylation domains within the synthetase multienzymes. Formation of hydroxmic acid by trapping of activated carboxyl group with hydroxylamine is an alternative method of assay for enzymes involved in the formation of acyladenylate. Hydroxamic acid can be converted to its ferric complex and detected spectrophotometrically.

NRPS is an assemblage of peptides of wide structural diversity and biological activity. For recognition, activation and modification of each amino incorporated, they have a different unit structure, and each unit is responsible for its specific function to finally form a peptide product (Lautru \& Challis 2004). The number and order of unit in the NRPSs is responsible for the determination of size and sequence of NRP.

NRPS chain extension unit contains three domains:

1. Adenylation domain (A): Adenylation domain specifically recognises the substrate and catalyses the adenylation of its carboxyl group.

2. Thiolation domain (T): Thiolation domain is also known as peptidyl carrier protein (PCP) domain. It uses terminal thiol of a post-translationally installed phosphopantetheine arm to capture the activated carboxyl group of the adenylate.

3. Condensation domain $(\mathrm{C})$ : Catalyses acylation of the resulting thioester with activated acyl group 
attached to the $\mathrm{T}$ domains in upstream unit. In some NRPS unit, $C$ domain is replaced by a heterocyclisation (CY) domain that catalyses hetrocycle formation by a reaction of $\beta$-amino thiol group in the substrate attached to the $\mathrm{T}$ domain of the upstream unit.

Chain initiation unit contains only $\mathrm{A}$ and $\mathrm{T}$ domains. The growing chain is covalently bound to the $\mathrm{T}$ domain in successive unit throughout the assembly process.

Thioesterase domain (TE): This domain is usually present in the final unit. Hydrolysis or cyclisation results in the release of assembled chain from the NRPS. Some TE domains catalyse NADH-dependent cleavage of the acyl thioester attached to the T domain (Nadia \& Challis 2009).

(B) NRPS-Independent biosynthesis

In comparison to the NRPS-dependent pathway, the enzymology of non-ribosomal-peptide-synthe- tases-independent siderophore (NIS) biosynthesis was overlooked for almost three decades. The first genetic characterisation of the NIS biosynthetic pathway to aerobactin was reported by Neilands and co-workers in 1980 (DeLorenzo \& Neilands 1986; Challis 2005). The siderophore aerobactin is a common metabolic product of different bacteria including Vibrio, Yersinia, Salmonella and E. coli (Challis 2005). The enzymes involved in aerobactin

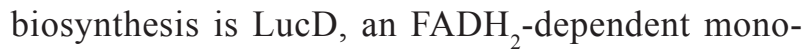
oxygenase that convert L-lysine to L-N6-huydroyllysine using molecular oxygen as a co-substrate (Challis 2005). The enzymes envolved possess substrate-specific properties. According to the biochemical characterisation, different NIS synthetase were identified, for example, DesD, a cluster of gene des $\mathrm{ABCD}$, pubC and put AB (Ledyand \& Buttler 1997; Challis 2005; Barona et al. 2006; Kadi et al. 2008).

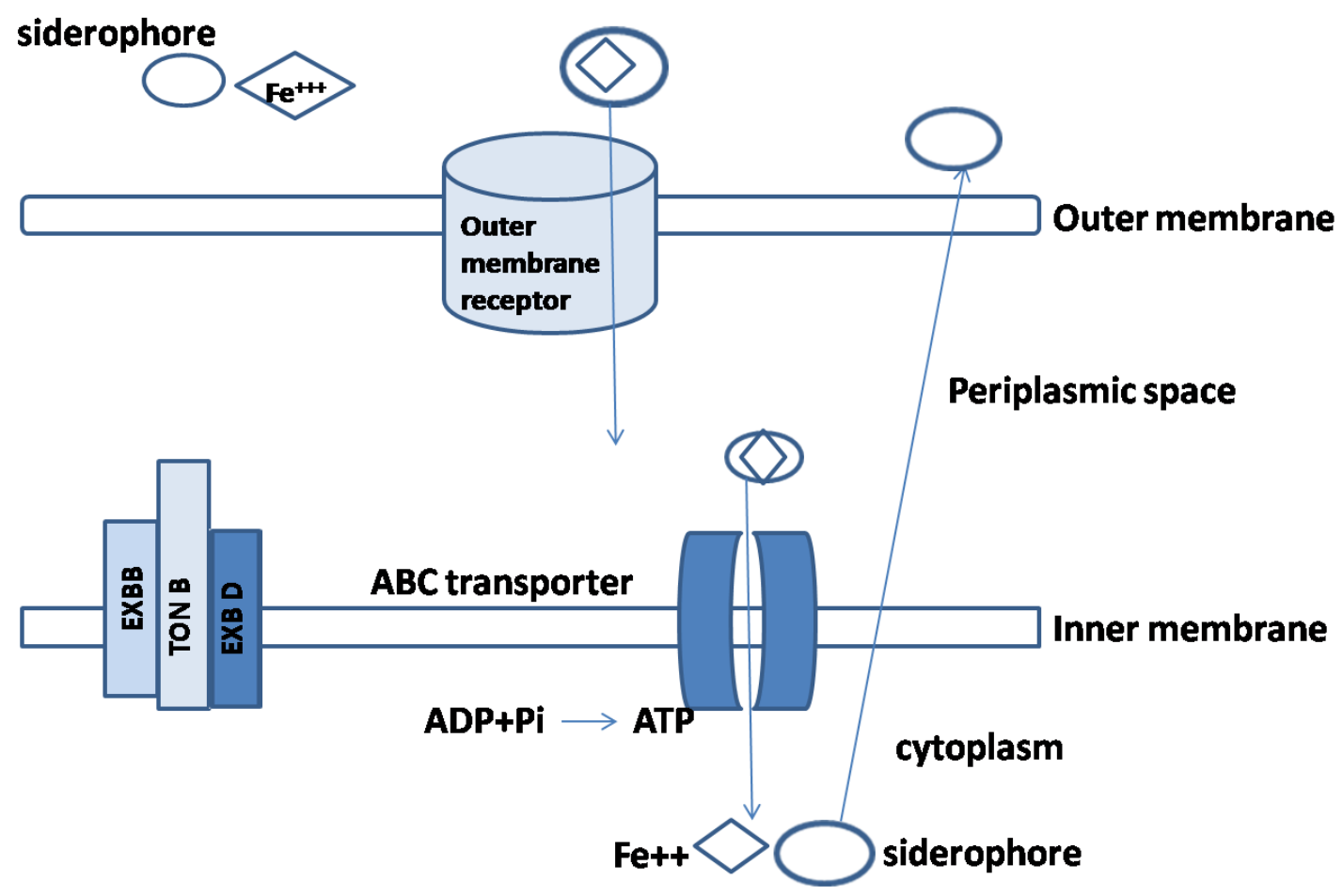

Figure 1. Transport of iron across the outer and inner membrane:

- Outer membrane contains receptor for binding and transporting the siderophore-iron complex to the periplasmic space.

- The siderophore-iron complex in the periplasmic space binds to periplasmic binding protein and is transported via $\mathrm{ABC}$ transporters composed of a protein channel in the cytoplasmic membrane to the cytosol.

- TonB, ExbB and ExbD are inner membrane protein complex that helps for the transportation of siderophoreiron complex across the outer memebrane. 


\section{Transport of Fe by Siderophores}

Siderophore trap traces of iron under the form of very stable complexes (Winkelmann 1991) as they are excreted by iron-starved microorganisms, and after the complexes have formed, they are internalised into the cell by specific cell receptors (Neilands 1982). Microorganisms including bacteria and fungi use siderophores to fulfill their iron requirements. To transport iron in the cytoplasm, bacteria capture iron-loaded siderophores at the cell surface and transport them into the cytosol. The binding constants of siderophores for Fe (III) are extremely high, implying that these compounds can effectively scavenge $\mathrm{Fe}$ (III) from a variety of complexes found in natural environment (Stintzi et al. 2000; Bernd \& Rehm 2008).

In gram-negative bacteria, this typically requires a combination of protein pattern:

- An outer membrane receptor that specifically binds the ferric-siderophore complex on the outer membrane and transfer it into the periplasm.

- A protein complex containing TonB transduces energy from the proton motive force into transport-proficient structural changes of the receptor.
- A binding protein located in the periplasm transfers the siderophore bound iron to cytoplasmic-membrane-associated trasporter.

Once released into the periplasm, siderophore are rapidly bound by the specific periplasmic binding protein FhvA (hydroxamate siderophores) (Coulton et al. 1986), FepB (Enterobactin) and FecB (ferric dicitrate) (Pressler et al. 1988).

The membrane-associated transporter or $\mathrm{ABC}$ transporter composed of a protein channel in the cytoplasmic membrane coupled with a cytoplasmic ATPase that envolves ferric siderophore internalisation at the expense of ATP hydrolysis in the cytoplasm (Figure 1).

The ABC transporter system is assembled of two proteins, one to separate the membrane acting as a permease and a second on which it can hydrolyse to provide the energy for transport. Transmembrane permease Fhu B for hydroximate, FepDG for enterobactins and $\mathrm{Fec} \mathrm{CA}$ for ferric dicitrate.

Ferric siderophores are released from the transport system at the cytoplasmic side of the cytoplasmic membrane. Eventually, iron is rapidly released from the siderophore complex via reduction. Different iron transport mechanism has been suggested for an outer membrane transport of pyoverdine
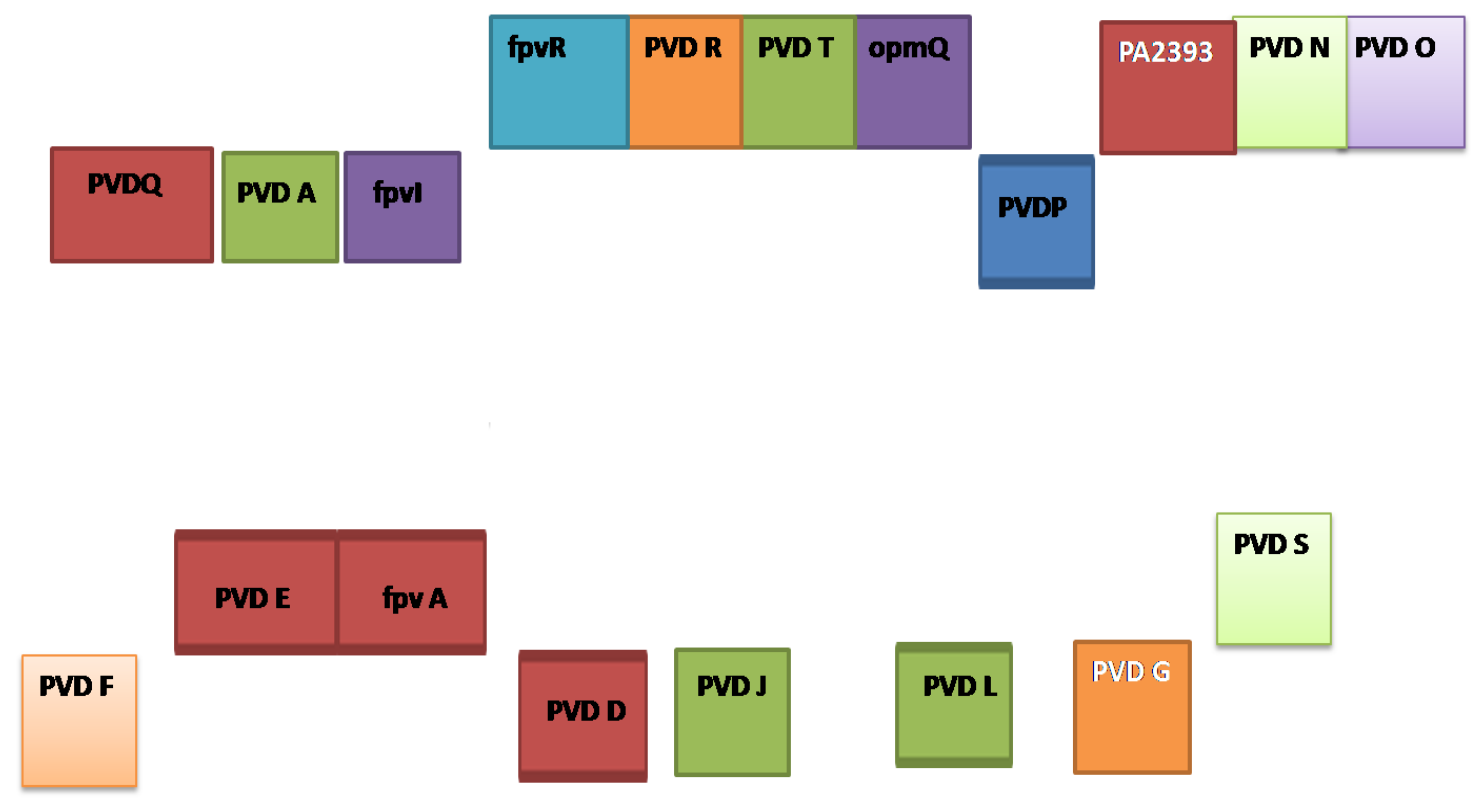

Figure 2. Arrangement of genes involved in siderophore biosynthesis in Pseudomonas aeruginosa as per the ORF region 
via the FpvA receptor in Pseudomonas aeruginosa The ligand exchange step occurs at the cell surface and involves the exchange of iron from a ferric pyoverdine to an iron-free pyoverdine strongly bound to the receptor FpvA. This mechanism suggest an increase in concentration of iron-free siderophore (Schalk et al. 2001) .

\section{Genes involved in siderophore biosynthesis}

Many species of Pseudomonas produce fluorescent siderophore. There is extensive homology between the DNA from different species, consistent with the suggestion that the different siderophore synthesis genes have evolved from the same ancestor set of gene (Hohnadel \& Meyer 1988; Rombel \& Lamont 1992), suggested the characteristics of pseudobactins and pyoverdin involved in the synthesis of pigments consist of achromophore joined to a short peptide; the chromophore is conserved between species, whereas the exact nature of the peptide is species specific, with differences reflecting specificities of uptake (Hohnadel \& Meyer 1988) (Figure 2, Table 2).

\section{Siderophore uptake regulation}

Protein named Fur (ferric uptake regulator) has been identified, which is responsible for transcriptional regulation of these genes. Fur gene product acts as a classical repressor requiring $\mathrm{Fe}^{2+}$ as an activator. When the iron concentration is high, fur forms a complex with $\mathrm{Fe}^{2+}$; in the promoter region, Fur binding prevents transcription of these genes. Under the conditions of iron deficiency, $\mathrm{Fe}^{2+}$ is removed from Fur, and fur-dependant genes are transcribed. Thus Fur regulates the oxidation state of the main components of iron metabolism (Hall \& Foster 1996; Bsat et al.1998; Hantke 2001).

Fur is related to the repression of genes involved in biosynthesis, export and import of siderophore (Figure 3).

\section{Application and importance of siderophore}

The importance of microbial siderophores extends beyond their immediate role in microbial physiology and their role in biotechnology. Applications of microbial siderophores for sustainability is enormous. These are produced by various bacteria

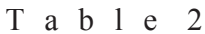

Genes involved in siderophore production

\begin{tabular}{|c|c|c|}
\hline Gene & ORF & Function \\
\hline pvdA & PA2386 & Ornithine hydroxylase (Visca et al. 1994) \\
\hline fpvI & PA2387. & $\begin{array}{l}\text { ECF sigma factor required for the expression of fpvA (Beare } \\
\text { et al. 2003) }\end{array}$ \\
\hline fpvR & PA2388 & $\begin{array}{l}\text { Anti-sigma factor for PvdS and FpvI (Lamont \& Martin 2003, } \\
\text { Beare et al. 2003) }\end{array}$ \\
\hline pvdF & PA2396. & N5-Hydroxyornithine transformylase (McMorran et al. 2001) \\
\hline pvdE & PA2397 & ABC transporter (secretion) (McMorran et al. 1996) \\
\hline fpvA & PA2398 & Ferripyoverdine receptor protein (Poole et al. 1993) \\
\hline pvdD & PA2399 & Pyoverdine peptide synthetase (Merriman et al. 1995) \\
\hline pvdJ & PA2400/1 & Pyoverdine peptide synthetase (Lehoux 2000) \\
\hline pvdI & PA2402 & Pyoverdine peptide synthetase (Lehoux 2000) \\
\hline pvdS ECF iron sigma factor & PA2426 & $\begin{array}{l}\text { ECF iron sigma factor (Cunliffe et al.1995; Miyazaki et al. } \\
\text { 1995) }\end{array}$ \\
\hline pvcABCD & PA2254-PA2257 1996 & Synthesis of the pyoverdinechromophore (Stintzi et al. 1999) \\
\hline
\end{tabular}


having wide application in various field such as agriculture to improve soil fertility and biocontrol, environmental application and medicinal application.

\section{Agricultural application}

Most soil microorganisms can promote mineral weathering by the production of siderophores. Siderophores provide an efficient $\mathrm{Fe}$-acquisition system because of its high affinity for Fe (III) complexation by means of mineral dissolution (McGrath et al. 1995; Kraemer 2004). Siderophores plays a significant role in iron dissolution, making it available for microorganisms and plants. Inoculation of soil with pseudobactin produced by Pseudomonas putida increases growth and yield of various plants (Kloepper et al. 1980).

Although there is sufficient iron in most soils for plant growth, plant iron deficiency is a problem in calcareous soil, because of the low solubility of iron (III) hydroxide. Calcareous soil accounts for $30 \%$ of the world's farmland. Under such conditions, graminaceous plants (grasses, cereals and rice) secrete phytosiderophores into the soil. Poaceae (grasses) including agriculturally important species such as barley and wheat are able to efficiently sequester iron by releasing phytosiderophores via their root into the surrounding soil rhizosphere (Hershko et al. 2002). Evidences suggest that plants have an ability to incorporate and use the $\mathrm{Fe}^{3+}$ of siderophores into their biomass and this was confirmed at molecular level also. The plant's enzyme NADH was able to function as ferric siderophore reductase indicating that plants accept iron through available iron siderophore chelates (Becker et al. 1985; Castignetti \& Smarrelli 1986) increasing the availability of iron. Plants such as oats are able to assimilate iron via these microbial siderophores. Application of microbial siderophorogenic bioinoculants have been extensively studied; it was found that this approach has protected groundnut crop from iron chlorosis. An improvement in overall growth and health of plants has been observed after treatment of seeds with siderophorogenic bioinoculants. Increased per-

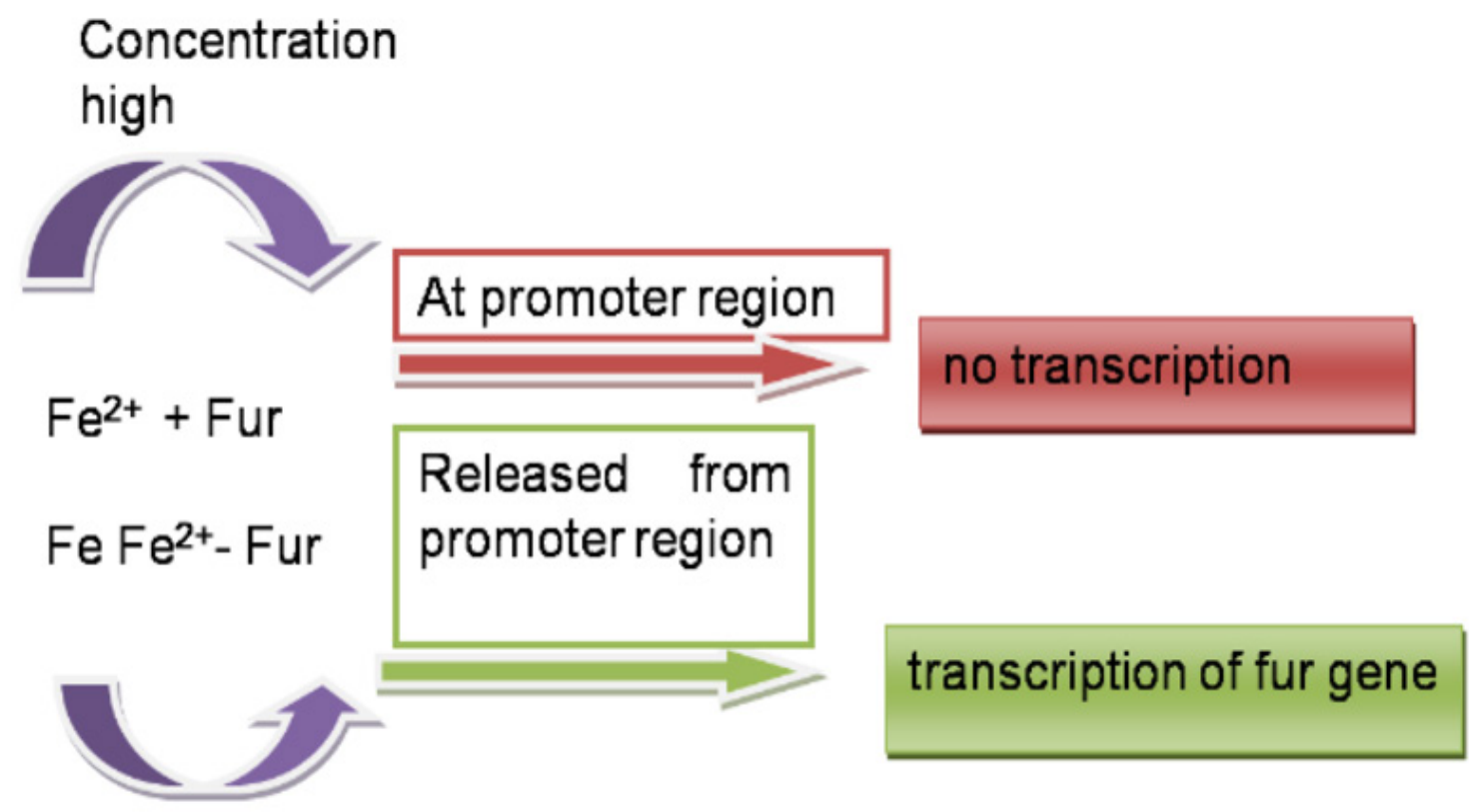

\section{Concentration low}

Figure 3. Regulation model of siderophore profuction because of Fur repression: Fur protein (ferric uptake regulator) is responsible for the transcriptional regulation of iron uptake. High iron concentration leads to the formation of Fur and $\mathrm{Fe}^{2+}$ complex in the promoter region, preventing the transcription of genes involved in transport, whilst at low concentration, $\mathrm{Fe}^{2+}$ is released from Fur proteins, leading to the transcription of iron transporting genes 
centage of germination, root ramification, nodulation, height, foliage and chlorophyll content were achieved only because of seed bacterisation with siderophoregenic Pseudomonas (Manwar et al. 2001). The direct benefits of bacterial siderophores on the growth of plants have been demonstrated in several different types of experiments. For example, (i) several studies using radiolabelled ferric siderophores as a sole source of iron showed that plants are able to take up the labelled iron, (ii) mung bean plants inoculated with the siderophore-producing Pseudomonas strain GRP3 and grown under iron-limiting conditions showed reduced chlorotic symptoms and an enhanced chlorophyll level compared to uninoculated plants (Sharma et al. 2003), (iii) an increase in iron inside plant tissues of Arabidopsis thaliana plants because of uptake of $\mathrm{Fe}-$ pyoverdine complex synthesised by Pseudomonas fluorescens $\mathrm{C} 7$ to improved plant growth (Vansuyt et al. 2007). The provision of iron to plants by soil bacteria is even more important when the plants are exposed to an environmental stress such as heavy metal pollution. In these cases, siderophores help to alleviate the stresses imposed on plants by high soil levels of heavy metals.

The repeated and continuous use of fungicides has led to the development of fungal-resistant strains, transforming fungicides ineffective. Microbial metabolites may help improve the control of plant pathogens either by enhancing the action of antagonistic microorganisms or by providing tools to develop healthier alternatives than synthetic chemical fungicides. Some bacterial strains that do not use any other means of biocontrol can act as biocontrol agents using the siderophores that they produce. Some studies have included the use of mutants that were defective in siderophore production and found that these strains were less effective than the wild-type strains at protecting plants against fungal pathogens (Buysens et al. 1996). On the other hand, one study observed that siderophore overproducing mutants were more effective at protecting plants against fungal pathogens (Vandenbergh \& Gonzalez 1984). Fluorescent Pseudomonads form a line of siderophores associated with improved plant growth through a direct effect on the plant through control of noxious organisms in the soil. Many bacteria suppress the growth of deleterious microorganism by the production of siderophore, antibiotics and cyanide (Husen 2003). Siderophores are themselves growth inhibitors of various phytopathogenic fungi, such as Phytophthora parasitica (Seuk et al. 1988), Phythium ultimum (Hamdan et al. 1991), Fusarium oxysporum veri dianthi (Buysens et al. 1996) and Sclerotinia sclerotiorum (Kraemer et al. 2006).

\section{Clinical applications}

In the treatment of thalassemia and certain other anemias, periodic whole blood transfusions are required (Pietrangelo et al. 2002). A siderophore from Streptomyces pilosus, desfarrioxamine B, is marketed as mesylate salt under the trade name Desferol and is advocated for the removal of excess iron resulting from the suppurative therapy for Thalassemia. As there is no specific physiological mechanism for the excretion of iron in man, continued transfusion therapy leads to a steady buildup of iron overload diseases such as hemochromatosis and hemosiderosis, and accidental iron poisoning, require the removal of iron from the body, especially from the liver. Such disease can be efficiently treated with siderophore-based drug and siderophore act as principal model (Chua et al. 2003).

The potency of common antibiotics has been elevated by binding into the iron-binding functional groups of siderophores. Siderophore used for the clearance of non-transferrin bound iron in serum that occurs in cancer therapy is a result of some chemotherapies (Chua et al. 2003). Antimalarial siderophore have been found to be useful in the treatment of malaria caused by Plasmodium falciparum (Gysin et al. 1991). Siderophore produced by $K$. pneumoniae act as antimalarial agent (Simon et al. 1993). Malaria parasites is highly dependent on $\mathrm{Fe}^{3+}$ for its growth. Its growth is arrested in the presence of $\mathrm{Fe}^{3+}$ chelators. Iron sources affected by desfemoxamine (DFO) and related hydroxamates reside inside the parasite and not at the level of host red blood cell (RBC) or serum source. Possible mechanisms involved in the antimalarial action of these iron chelators are sequestration of $\mathrm{Fe}^{3+}$ from vital sources, such as storage proteins; low-molecular-weight siderophores; iron centers of key parasite enzymes, such as ribonucleotide reductase; or the scavenging of iron from degraded hemoglobin. DFO is an iron chelator with remarkable therapeutic performance, 
including antimalarial activity both in vitro and in vivo. However, because of its relatively slow and apparently selective permeation into the advanced growth stages of cells infected by $P$. falciparum, its biological activity is slow to develop, that is, it demands relatively long exposures of cells at mature stages of parasite growth. The major prototype of a novel family of antimalarial agents that is termed as reversed siderophore (RSF, siderophores with relatively high lipophilic properties) subserve their permeation into cells. Because $\mathrm{Fe}^{3+}$ binding to RSFs completely abolished their antimalarial effect, it was implied that the arrest of parasite growth involved sequestration of critical iron and not the formation of intracellular toxic $\mathrm{Fe}^{3+}$ ligand complexes, as proposed for other classes of iron $\mathrm{Fe}^{3+}$ chelators. The studies indicate that permeation plays a dominant role in the antimalarial activity of iron chelators and is a major determinant in the irreversible inhibition of parasite growth (Garbisu \& Alkorta 1997).

Sideromycin an iron-chelating antibiotic produced by Streptomyces species showed good antimicrobial activity.

\section{Environmental applications}

Although heavy metals $(\mathrm{Cd}, \mathrm{Cr}, \mathrm{Cu}, \mathrm{Hg}, \mathrm{Pb}$ and $\mathrm{Ni}$ ) are naturally present in the soil, geologic and anthropogenic activities increase the concentration of these elements to amounts that are harmful to both plants and animals. Excessive accumulation of heavy metals is toxic to most plants, water and soil possing a major environmental and human health problem. Some of the activities are mining and smelting of metals, burning of fossil fuels, use of fertilisers and pesticides in agriculture, production of batteries and other metal products in industries, sewage sludge and municipal waste disposal. Heavy metals cannot be degraded during bioremediation but can only be transformed from one organic complex or oxidation state to another. Owing to a change in their oxidation state, heavy metals can be transformed to less toxic, easily volatilised, more water soluble (and thus can be removed through leaching), less water soluble (which allows them to precipitate and become easily removed from the environment) or less bioavailable (Wang et al. 1989). Several microorganisms especially bacteria (Bacillus subtilis, P. putida and Enterobacter cloacae) have been successfully used for the reduction of $\mathrm{Cr}(\mathrm{VI})$ to the less toxic Cr (III) (Lelie et al. 1999; Haja et al. 2010). B. subtilis has also been reported to reduce nonmetallic elements. For instance, Garbisu et al. (1995) recorded that $B$. subtilis reduced the selenite to the less toxic element Se. B. cereus and B. thuringiensis increase the extraction of $\mathrm{Cd}$ and $\mathrm{Zn}$ from $\mathrm{Cd}$-rich soil and soil polluted with effluent from metal industry (Ruggiero et al. 2000). It is assumed that the production of siderophore by bacteria have facilitated the extraction of these metals from the soil; this is because heavy metals have been reported to simulate the production of siderophore and this consequently affects their bioavailability (Von Gunten \& Benes 1995). For instance, siderophore production by $A$. vinelandii was increased in the presence of $\mathrm{Zn}$ (II) Siderophore-producing rhizobacteria (SPR) are a group of plant-growth-promoting rhizobacteria, being able to play an important role in assisting the phytoremediation of heavy-metals-contaminated soils. Hence, heavy metals influence the activities of siderophore-producing bacteria which in turn increases the mobility and extraction of these metals in soil. Siderophores have the potential to resolve these environmental problems such as heavy metal accumulation, rust removal, biofouling, dye degradation, sewage treatment and bioleaching. Hydroxamate-type siderophore present in soil plays important role to immobilise these heavy metals.

Siderophores may be used to treat radioactive waste before storage (Von Gunten \& Benes 1995; Bouby et al. 1998). Some species of fungi such as Fusarium sp. and bacteria such as P. aerugino$s a$ were able to produce element-specific ligands (siderophores) that are able to change $\mathrm{pH}$ and enhance the chelation of some elements such as Uranium $\left(\mathrm{U}^{6+}\right)$ and Thorium $\left(\mathrm{Th}^{4+}\right)$ (Joshi et al. 2014).

$P$. putida increases its siderophore secretion in response to the availability of benzyl alcohol, a model aromatic substrate. Accelerated siderophore secretion in response to aromatic substrates provides an iron 'boost' which is required for the effective functioning of the iron-dependent oxygenases responsible for ring opening. Stimulated siderophore secretion might be a key factor in successful integration and proliferation of this organism as a bioaugmentation agent for aromatic degradation. It not only facilitates efficient aro- 
matic utilisation but also provides better opportunities for iron assimilation amongst diverse microbial communities, thereby ensuring better survival and proliferation (Joshi et al. 2014).

Enormous volumes of effluent are generated at different stages of textile manufacturing loading waste residues such as toxic reactive dyes, chlorolignin residues and dark colouration to the water bodies resulting the change in the ecological balance. The biological breakdown of the chlorolignin residues and the chromophoric groups responsible for the dark coloration of the textile effluent can be accomplished by the use of enzymes and siderophores from the white rot fungus, Phanerochaete chrysosporium (Asamudo et al. 2005).

\section{CONCLUSIONS}

Microorganisms and plants sustain themselves under iron-deprived conditions by releasing siderophores. Bacteria produce four types of siderophores: hydroxamate, catecholate, salicylate and carboxylate. These siderophores play an important role in the extra cellular solubilisation of iron from minerals or organic substances. Some important siderophore-producing bacteria includes E. coli, Salmonella, K. pneumoniae, Vibrio cholerae, $V$. anguillarum, Aeromonas, Aerobacter raerogenes, Enterobacter, Yersinia and Mycobacterium species. Present review highlights recent updates in siderophore production, importance, structural/functional moiety and their source of isolation. A brief description about different $\mathrm{Fe}$-siderophore complexes, their transport and synthesis pathway (NRPS-dependent and NRPS-independent pathway) has been included. It also explains the genes involved in the biosynthesis of sideophore along with its regulation. Iron uptake system synthesises siderophore and represents central organic compound providing better health of plants. Understanding the chemical structures of different siderophores and the membrane receptors involved in $\mathrm{Fe}$ uptake has opened new areas for research.

\section{REFERENCES}

ABDALLAH, M.A. 1991. Pyoverdines and pseudobactins. In WILKELMANN,G. (Ed) CRC handbook of microbial iron chelates. Boca Raton, Florida : CRC Press. pp 139-152.

AHMED, E. - HOLMSTROM, S.J. 2014. Siderophores in environmental research: roles and applications. In Microbial Biotechnology, vol. 7, no. 3, pp. 196208.

HAJA, A.R. - MOHIDEENA, V. - THIRUMALAI ARASUC - NARAYANANB, K.R. - ZAHIR HUSSAIND, M.I. 2010. Bioremediation of heavy metal contaminated soil by the exigobacterium and accumulation of $\mathrm{Cd}, \mathrm{Ni}, \mathrm{Zn}$ and $\mathrm{Cu}$ from soil environment. In International Journal of Biological Technology, vol. 1, no. 2, pp. 94-101.

ALEXANDER, D.B. - ZUBERERM, D.A. 1991. Use of chrome azurol 'S regents to evaluate siderophore production by rhizosphere bacteria. In Biology and Fertility of Soils, vol. 12, pp. 39-45.

ALI, S.S. - VIDHALE, N.N. 2013. Bacterial Siderophore and their Application: A review. In International Journal of Current Microbiology Applied Sciences, vol. 2, no. 12, pp. 303-31.

ALI, T. - BYLUND, D. - ESSÉN, S.A. - LUNDSTRÖM, U.S. 2011. Liquid extraction of low molecular mass organic acids and hydroxamate siderophores from boreal forest soil. In Soil Biology and Biochemistry, vol. 43, pp. 2417-2422.

ASAMUDO, N.U. - DABA, A.S. - EZERONYE, O.U. 2005 Bioremediation of textile effluent using Phanerochaete chrysosporium. In African Journal of Biotechnology, vol. 4, no. 13, pp. 1548-1553.

BARONA, G.F. - LAUTRU, S. - FRANCOU, F.X. PERNODET, P.L.J.L. - CHALLIS, G.L. 2006. Multiple biosynthetic and uptake systems mediate siderophore-dependent iron acquisition in Streptomyces coelicolor A3(2) and Streptomycesambofaciens ATCC 23877. In Microbiology, vol. 152, no. 11, pp. $3355-$ 3366.

BEARE, P.A. - FOR, R.J. - MARTIN, L.W. - LAMONT, I.L. 2003. Siderophore-mediated cell signalling in Pseudomonas aeruginosa: divergent pathways regulate virulence factor production and siderophore receptor synthesis. In Molecular Microbiology, vol.47, pp. 195-207. DOI: 10.1046/j.13652958.2003.03288.x.

BECKER, J.O. - MESSENS, E. - HEDGES, R.W. 1985. The influence of agrobactin on the uptake of ferric iron by plants. In FEMS microbiology letters, vol. 31, no. 3, pp. 171-175. DOI: 10.1111/j.1574-6968.1985. tb01145.x.

BERND, H. - REHM, A. 2008. Biotechnological relevance of Pseudomonads. In BERND, H. - REHM, A. (Eds) Pseudomonas. Model Organism, Pathogen, Cell Factory. Weinheim, Germany : Wiley-VCH Verlag $\mathrm{GmbH}$ and Co. KGaA. p. 377. ISBN 978-3-52731914-5.

BICKEL, H. - BOSSHARDT, R. - GÄUMANN, E. - REUSSER, P. - VISCHER, E. - VOSER, W. - WETTSTEIN, A. - ZÄHNER, H. 1960. Stoffwechselprodukte von 
Actinomyceten. Über die Isolierung and Characterisierung der Ferrioxamine A-F, neuer Wuchsstoffe der Sideramin-Gruppe. In Helvetica Chimica Acta, vol. 43, pp. 2118-2128. DOI: 10.1002/hlca.19600430731.

BOUBY, M. - BILLARD, I. - MACCORDICK, J. 1998. Complexation of Th (IV) with the siderophore pyoverdine A. In Journal of Alloys and Compounds, vol. 273, pp. 206-210.

BSAT, N. - HERBIG, A. - CASILLAS-MARTINEZ, L. - SETLOW, P. - HELMANN, J.D. 1998. Bacillus subtilis contains multiple Fur homologues: identification of the iron uptake (Fur) and peroxidase regulon (PerR) repressors. In Molecular Microbiology, vol. 29, pp.189-198.

BUSS, H.L. - LUTTGE, A. - BRANTLEY, S.L. 2007. Etch pit formation on iron silicate surfaces during siderophore-promoted dissolution. In Chemical Geology, vol. 240, pp. 326-342. DOI:10.1016/j.chemgeo.2007.03.003.

BUYER J.S. - LORENZO, V.DE. - NEILANDS, J.B. 1991. Production of the siderophore aerobactin by a halophilic Pseudomonad. In Applied and Enviromental Microbiology, vol. 57, no. 8, pp. 2246-2250.

BUYSENS, S. - HEUNGENS, K. - POPPE, J. - HOFTE, M. 1996. Involvement of Pyochelin and pioverdin in suppression of Pseudomonas aeruginosa 7 NSK2. In $\mathrm{Ap}$ plied and Environmental Microbiology, vol. 62, no. 3, pp. 865-871.

BUYSENS, S. - HEUNGENS, K. - POPPE, J. - HOFTE, M. 1996. Involvement of pyochelin and pyoverdin in suppression of Pythium-induced damping-off of tomato by Pseudomonas aeruginosa 7 NSK2. In $\mathrm{Ap}$ plied and Environmental Microbiology, vol. 62, no. 3 , pp. 865-871.

CASTIGNETTI, D. - SMARRELLI, J.R. 1986. Siderophores, the iron nutrition of plants, and nitrate reductase. In Federation of European Biochemical Societies (FEBS) Letter, vol. 209, pp. 147-151.

CHALLIS, G.L. 2005. Widely distributed bacterial pathway for siderophore biosynthesis independent of nonribosomal peptide synthetases. In ChemBioChem, vol.6, pp. 601-611. DOI: 10.1002/cbic.200400283.

CHUA, A.C. - INGRAM, H.A. - RAYMOND, K.N. BAKER, E. 2003. Multidentate pyridinones inhibit the metabolism of nontransferrin-bound iron by hepatocytes and hepatoma cells. In European Journal of Biochemistry, vol. 270, pp. 1689-1698.

CLINE, G.R. - POWELL, P.E. - SZANisZlo, P.J. REID, C.P.P. 1982. Comparison of abilities of hydroxamic, synthetic, and other natural organic acids to chelate iron and other irons in nutrient solution. In Soil Science Society of America Journal, vol. 46, pp. $1158-1164$.

CORBIN, J.L. - BULEN, W.A. 1969. The isolation and identification of 2,3-dihydroxybenzoic acid and 2-N,6-N-di(2,3-dihydroxy benzoy1)-L-lysine formed by iron-deficient Azotobacter. In Biochemistry, vol. 8, pp. 757-762.

CORNISH, A.S. - PAGE, W.J. 1995. Production of the tri catecholate siderophore protochelin by Azotobactervinelandii. In BioMetals, vol. 8, pp. 332-338.
CORNISH, A.S. - PAGE, W.J. 1998. The catecholate siderophores of Azotobacter vinelandii: their affinity for iron and role in oxygen stress management. In Microbiology, vol. 144, no. 7, pp. 1747-1754.

COULTON, J.W. - MASON, P. - CAMERON, D.R. CARMEL, G. - JEAN, R. - RODE, H.N. 1986. Protein fusions of beta-galactosidase to the ferrichrome-iron receptor of Escherichia coli K-12. In Journal of Bacteriology, vol. 165, no. 1, pp. 181-92.

CROSA, J.H. - WALSH, C.T. 2002. Genetics and assembly line enzymology of siderophore biosynthesis in bacteria. In Microbiology and Molecular Biology Reviews, vol. 66, pp. 223-249.

CUNLIFFE, H.E. - MERRIMAN, T.R. - LAMONT, I.L. 1995. Cloning and characterization of $p v d S$, a gene required for pyoverdine synthesis in Pseudomonas aeruginosa: PvdS is probably an alternative sigma factor. In Journal of Bacteriology, vol. 177, pp. 2744-2750.

DE LORENZO, V. - NEILANDS, J.B. 1986. Characterization of iucA and iucC genes of the aerobactin system of plasmid ColV-K30 in Escherichia coli. In Journal of Bacteriology, vol. 167, pp. 350-355.

DE VOSS, J.J. - RUTTER, K. - SCHROEDER, B.G. BARRY III, C.E. 1999. Iron acquisition and metabolism by mycobacteria. In Journal of Bacteriology, vol. 181, pp. 4443-4451.

DRECHSEL, H. - JUNG, G. - WINKELMANN, G. 1992. Stereochemical characterization of rhizoferrin and identification of its dehydration products. In BioMetals, vol. 5, pp.141-148.

GARBISU, C. - ALKORTA, I. 1997. Bioremediation: principles and future. In Journal of Clean Technology, Environmental Toxicology and Occupational Medicine, vol. 6, no. 4, pp. 351-366.

GARBISU, C. - GONZÁLEZ, S. - YANG, W.H. 1995. Physiological mechanisms regulating the conversion of selenite to elemental selenium by Bacillus subtilis. In BioFactors, vol. 5, no. 1, pp. 29-37.

GREGORY, J.A. - LI, F. - TOMOSADA, L.M. - COX, C.J. 2012. Topol AB, Algae - produced Pfs25 elicits antibodies that inhibit malaria transmission. In PLoS $O N E$, vol. 7, no. 5, pp. 371-379. DOI:10.1371/journal.pone. 0037179 .

GYSIN, J. - CRENN, Y. - PEREIRA, DA S. - LUIZ BRETON, C. 1991. Siderophores as anti parasitic agents. US patent 5, pp.192-807.

HALL, H.K. - FOSTER, J.W. 1996. The role of fur in the acid tolerance response of Salmonella typhimurium is physiologically and genetically separable from its role in iron acquisition. In Journal of Bacteriology, vol. 178, pp. 5683-5691.

HAMDAN, H. - WELLER, D. - THOMASHOW, L. 1991. Relative importance of fluorescens siderophores and other factors in biological control of Gaeumannomyces graminis var. Tritici by Pseudomonas fluorescens 2-79 and M4-80R. In Applied and Environmental Microbiology, vol. 57, no. 11, pp. 3270-3277.

HANS, P.F. - KRASTEL, P. - MULLER, J. - GEBHARDT, K. - ZEECK, A. 2001. Enterobactin: the characteris- 
tic catecholate siderophore of Enterobacteriaceae is produced by Streptomyces species. In FEMS Microbiology Letters, vol. 196, no. 2, pp. 147-151.

HANTKE, K. 2001. Iron and metal regulation in bacteria. In Current Opinion in Microbiology, vol. 4, pp. $172-177$.

HERSHKO, C. - LINK, G. - KONIJN, A.M. 2002. Cardioprotective effect of iron chelators. In HERSHKO, C. (Ed) Iron Chelation Theraphy. New York : Kluwer Academic / Plenum Publishers. pp. 77-89.

HIDER, R.C. - KONG, X. 2010. Chemistry and biology of siderophores. In Natural Product Reports, vol. 27, no. 5 , pp. $637-57$.

HOHNADEL, D. - MEYER, J.M. 1988. Specificity of pyoverdine-mediated iron uptake among fluorescent Pseudomonas strains. In Journal of Bacteriology, vol. 170, pp. 4865-4873.

HUSEN, E. 2003. Screening of soil bacteria for plant growth promotion activities in vitro. In Indonesian Journal of Agricultural Science, vol. 4, no. 1, pp. 27-31.

ISHIMARU, Y. - TAKAHASHI, R. - BASHIR, K. - SHIMO, H. - SENOURA, T. - SUGIMOTO, K. - ONO, K. - YANO, M. - ISHIKAWA, S. - ARAO, T. - NAKANISHI, H. - NISHIZAWA, N.K. 2012. Characterizing the role of rice in manganese, iron and cadmium transport. In Scientific reports, vol. 2, pp. 286.

JALAL, M.A.F. - HOSSAIN, M.B. - VANDERHELM, D. - SANDERSLOEHR, J. - ACTIS, L.A. - CROSA, J.H. 1989. Structure of anguibactin, a unique plasmid-related bacterial siderophore from the fish pathogen Vibrio anguillarum. In Journal of the American Chemical Society, vol. 111, pp. 292-296.

JALAL, M.A.F. - VAN DER HELM, D. 1991. Isolation and spectroscopic identification of fungal siderophores. CRC Handbook of Microbial Iron Chelates Winkelmann G, CRC Press; Boca Raton, pp. 235-269.

JOHNSON, J.R. - MOSELEY, S.L. - ROBERTS, P.L. STAMM, W.E. 1988. Aerobactin and other virulence factor genes among strains of Escherichia coli causing urosepsis: association with patient characteristics. In Infection and Immunity, vol. 56, no. 2, pp. 405412.

JOSHI, H. - DAVE, R. - VENUGOPALAN, V.P. 2014. Pumping iron to keep fit: modulation of siderophore secretion helps efficient aromatic utilization in $P$ seudomonas putida KT2440. In Microbiology, vol. 160, pp. 1393-400. DOI: 10.1099/mic.0.079277-0.

KADI, N. - ARBACHE, S. - SONG, L. - OVES-COSTALES, D. - CHALLIS, G.L. 2008. Identification of a gene cluster that directs putrebactin biosynthesis in Shewanella species: PubC catalyzes cyclodimerization of N-hydroxy-Nsuccinylputrescine. In Journal of the American Chemical Society, vol. 130, pp. 1045810459.

KANNAHI, M. - SENBAGAM, N. 2014. Studies on siderophore production by microbial isolates obtained from rhizosphere soil and its antibacterial activity. In Journal of Chemical and Pharmaceutical Research, vol. 6 , no. 4, pp.1142-1145.
KLOEPPER, J.W. - LEONG, J. - TEINIZE, M. SCHROTH, M.N. 1980. Enhanced plant growth by siderophores produced by plantgrowth promoting rhizobacteria. In Nature, vol. 286, pp. 885-886.

KRAEMER, S.M. - CROWLEY, D. - KRETZSCHMAR, R. 2006. Siderophores in plant iron acquisition: Geochemical aspects. In Advances in Agronomy, vol. 91, pp. 1-46. DOI: 10.1016/S0065-2113(06)91001-3.

KRAEMER, S.M. 2004. Iron oxide dissolution and solubility in the presence of siderophores. In Aquatic Sciences, vol. 66, pp. 3-18. DOI: 10.1007/s00027003-0690-5.

LAMONT, I.L. - MARTIN, L.W. 2003. Identification and characterization of novel pyoverdine synthesis genes in Pseudomonas aeruginosa. In Microbiology, vol. 149, no. 4, pp. 833-842.

LANKFORD, C.E. 1973. Bacterial assimilation of iron. In Reviews in Microbiology, vol. 2, pp. 273-331. DOI: $10.3109 / 10408417309108388$.

LAUTRU, S. - CHALLIS, G.L. 2004. Substrate recognition by nonribosomal peptide synthetase multi-enzymes. In Microbiology, vol. 150, pp. 1629-1636. DOI 10.1099/mic.0.26837-0.

LEDYARD, K.M. - BUTTLER, A. 1997. Structure of putrebactin, a new dihydroxamate siderophore produced by Shewanella putrefaciens. In JBIC Journal of Biological Inorganic Chemistry, vol. 22, pp. 93-97. DOI: $10.1007 / \mathrm{s} 007750050110$.

LEHOUX, D. 2000. Genomics of the 35-kb locus and analysis of novel prdIJK genes implicated in pyoverdine biosynthesis in Pseudomonas aeruginosa. In Federation of European Biochemical Societies, vol. 190, pp. 141-146.

LOPER, J.E. - HENKEL, M.D. 1999. Utilization of heterologous siderophore enhances levels of iron available to Pseudomonas putida in rhizosphere. In Applied and Environmental Microbiology, vol. 65, no. 12, pp. 5357-5363.

MAHESHWARI, D.K. 2011. Plant growth promoting rhizobacteria: fundamentals and applications. In MAHESHWARI, D.K. (Ed) Plant Growth and Health Promoting Bacteria. Berlin, Heidelberg : Springer-Verlag. pp. 21-42. ISBN 978-3-642-13612-2.

MANWAR, A.V. - KHANDELWAL, S.R. - CHAUDHARI, B.L. - KOTHARI, R.M. - CHINCHOLKAR, S.B. 2001. Generic technology for assured biocontrol of groundnut infections leading to its yield improvement. In Chemical Weekly, vol. XL VI, no. 26, pp. $157-158$.

MARSCHNER, H. - ROMHELD, V. - KISSEL, M. 1986. Different strategies in higher plants in mobilization and uptake of iron. In Journal of Plant Nutrition, vol. 9 , pp. 695-713. DOI: 10.1080/01904168609363475.

McGRATh, S.P. - CHAUDRI, A.M. - GILLER, K.E. 1995. Long-term effects of metals in sewage sluge on soils, microorganisms and plants. In Journal of Industrial, vol. 14, no. 2, pp. 94-104. DOI: 10.1007/ BF01569890.

McMORRAN, B.J. - KUMARA, H.M.C. - SULLIVAN, K.S. - LAMONT, I.L. 2001. Involvement of a transformylase enzyme in siderophore synthesis in Pseu- 
domonasaeruginosa. In Microbiology, vol. 147, pp. 1517-1524.

McMORRAN, B.J. - MERRIMAN, M.E. - ROMBEL, I.T. - LAMONT, L.T. 1996. Characterisation of the $p v d E$ gene which is required for pyoverdine synthesisin Pseudomonas aeruginosa. In Gene, vol. 176, pp. $55-59$.

MENEELY, K.M. - LAMB, A.L. 2007. Biochemical characterization of an FAD-Dependent monooxygenase, the ornithine hydroxylase from Pseudomonas aeruginosa, suggests a novel reaction mechanism. In Biochemistry, vol. 46, pp. 11930-11937.

MERRIMAN, T.R. - MERRIMAN, M.E. - LAMONT, I.L. 1995. Nucleotidesequence of $p v d D$, a pyoverdine biosynthetic gene from Pseudomonas aeruginosa: PvdD has similarity to peptide synthetases. In Journal of Bacteriology, vol. 177, pp. 252-258.

MEYER, J.M. 2000. Pyoverdines: Pigments, siderophores and potential taxonomic markers of fluorescent Pseudomonas species. In Archives of Microbiology, vol. 174, no. 3, pp. 135-142.

MEYRIER, A. 1999. Urinary tract infection. In SCHRIER, R.W. - COHEN, A.H. - GLASSOCK, R.J. - GRÜNFELD, JP. (Eds) Atlas of diseases of the kidney 2. Oxford: Blackwell Science. ISBN 0-632-04387-3.

MINO, Y. - ISHIDA, T. - OTA, N. - INOUE, M. - NOMOTO, K. - TAKEMOTO, T. - TANAKA, H. - SUGIURA, Y. 1983. Mugineic acid-iron (III) complex:characterization and implication for absorption and transport of iron in gramineous plants. In Journal of the American Chemical Society, vol. 105, pp. 4671-4676. DOI: $10.1021 / \mathrm{ja} 00352 \mathrm{a} 024$.

MOSSIALOS, D. - OCHSNER, U. - BAYSSE, C. CHABLAIN, P. - PIRNAY, J.P. - KOEDAM, N. 2002. Identification of new, conserved, non-ribosomal peptide synthetases from fluorescent pseudomonads involved in the biosynthesis of the siderophore pyoverdine. In Molecular Microbiology, vol. 45 , no. 6, pp.1673-85. DOI: $10.1046 / \mathrm{j} .1365-$ 2958.2002.03120.x.

MUNEES, A. - MULUGETA, K. 2014. Mechanisms and applications of plant growth promoting rhizobacteria. In Current perspective Journal of King Saud University-Science, vol. 26, pp. 1-20.

MUNZINGER, M. - TARAZ, K. - BUDZIKIEWICZ, H. 1999. SS-rhizoferrin (enantio-rhizoferrin) - a siderophore of Ralstonia (Pseudomonas) pickettii DSM 6297 - the optical antipode of R, R-rhizoferrin isolated from fungi. In BioMetals, vol. 12, pp. 189-193.

NADIA, K. - CHALLIS, G.L. 2009. Complex enzymes in microbial natural product biosynthesis. In Methods in Enzymology, vol. 458, pp. 431-435.

NEILANDS, J.B. 1952. A crystalline organo-iron pigment from a rust fungus (Ustilagosphaerogena). In Journal of the American Chemical Society, vol. 74, no. 19 , pp. 4846-4847.

NEILANDS, J.B. 1981. Iron absorption and transport in microorganisms. In Annual Review of $\mathrm{Nu}$ trition, vol. 1, pp. 27-46. DOI: 10.1146/annurev. nu.01.070181.000331.
NEILANDS, J.B. 1982. Microbial iron transport comounds. In Annual Review of Microbiology, vol. 36, pp. 285309. DOI: 10.1146/annurev.mi.36.100182.001441.

NEILANDS, J.B. 1995. Siderophores: Structure and function of microbial iron transport compounds. In The Journal of Biological Chemistry, vol. 270, no. 45, pp. 26723-26726. DOI:10.1074/jbc.270.45.26723.

O'BRIEN, I.G. - COX, G.B. - GIBSON, F. 1970. Biologically active compounds containing 2, 3-dihydroxybenzoic acid and serine formed by Escherichia coli. In Biochimica et Biophysica Acta (BBA), vol. 201, no. 3, pp. 453-60. DOI:10.1016/0304-4165(70)901650 .

O'SULLIVAN, D.J. - O'GARA, F. 1992. Traits of fluorescent Pseudomonas spp. involved in suppression of plant root pathogens. In Microbiological Reviews, vol. 56, no. 4, pp. 662-676. DOI: 0146-0749/92/040662$15 \$ 02.00 / 0$

PAGE, W. - TIGERSTROM, V.M. 1988. Aminochelin, a catecholamine siderophore produced by Azotobactervinelandii. In Journal of General Microbiology, vol. 134, pp. 453-460. DOI: 10.1099/00221287-134-2453.

PIETRANGELO, A. 2002. Mechanism of iron toxicity. In HERSHKO, C. (Ed) Iron Chelation Theraphy. New York : Kluwer Academic/ Plenum Publishers, vol. 509, pp. 19-43.

POLLACK, J.R. - NEILANDS, J.B. 1970. Iron transport in Salmonella typhimurium: Mutants blocked in the Biosynthesis of Enterobactin. In Journal of Bacteriology, vol. 104, no. 2, pp. 635-639.

POOLE, K. - NESHAT, S. - KREBES, K. - HEINRICHS, D.E. 1993. Cloning and nucleotide sequence analysis of the ferripyoverdine receptor gene fpvA of Pseudomonas aeruginosa. In Journal of Bacteriology, vol. 175 , no. 15 , pp. $4597-4604$.

PRESSLER, U. - STAUDENMAIER, H. - ZIMMERMANN, L. - BRAUN, V. 1988. Genetics of the iron dicitrate transport system of Escherichia coli. In Journal of Bacteriology, vol. 170, pp. 2716-2724.

RAVEL, J. - CORNELIS, P. 2003. Genomics of pyoverdine - mediated iron uptake in pseudomonads. In Trends in Microbiology, vol. 11, pp. 195-200. DOI: $10.1111 /$ j.1365-2958.2008.06223.x.

RAYMOND, K.N. - EMILY, A.D. - SANGGOO, S.K. 2003. Enterobactin: An archetype for microbial iron transport. In Proceedings of the National Academy of Sciences of the United States of America, vol. 100, no. 7, pp. 3584-3588. DOI:10.1073/pnas.0630018100.

REICHARD, P.U. - KRAEMER, S.M. - FRAZIER, S.W. - KRETZSCHMAR, R. 2005. Goethite dissolution in the presence of phytosiderophores: rates, mechanisms, and the synergistic effect of oxalate. In Plant Soil, vol. 276, pp. 115-132.

RENSHAW, J.C. - ROBSON, G.D. - TRINCI, A.P.J. WIEBE, M.G. - LIVENS, F.R. - COLLISON, D. TAYLOR, R.J. 2002. Fungal siderophores: structures, functions and applications. In Mycological Research, vol. 106, pp. 1123-1142.

ROMBEL, I.T. - LAMONT, I.L. 1992. DNA homology between siderophore genes from fluorescent pseu- 
domonads. In Journal of General Microbiology, vol. 138, no. 1, pp. 181-187. DOI: 10.1099/00221287138-1-181.

RUGGiero, C.E. - NEU, M.P. - MATONIC, J.H. REILLY, S.D. 2000. Interactions of $\mathrm{Pu}$ with desferrioxamine siderophores can affect bioavailability and mobility. In Actinide Research Quarterly, 2nd/3rd Quarter, pp. 16-18.

SCHALK, I.J. - HANNAUER, M. - BRAUD, A. 2011. Minireview new roles for bacterial. In Enviromental Microbiology, vol. 13, no. 11, pp. 2844-54.

SCHALK, I.J. - HENNARD, C. - DUGAVE, C. - POOLE, K. - ABDAllAh, M.A. - PATTUS, F. 2001. Ironfree pyoverdin binds to its outer membrane receptor FpvA in Pseudomonas aeruginosa: a new mechanism for membrane iron transport. In Molecular Microbiol$o g y$, vol. 39, no. 2, pp. 351-60. DOI: 10.1046/j.13652958.2001.02207.x.

SCHWYN, B. - NEILANDS, J.B. 1987. Universal chemical assay for the detection and determination of siderophores. In Analytical Biochemistry, vol. 160, no. 1, pp. 47-56. DOI:10.1016/0003-2697(87)90612-9.

SEUK, C. - PAULITA, T. - BAKER, R. 1988. Attributes associate with increased bio-control activity of fluorescent Pseudomonads. In Journal of Plant Patholo$g y$, vol. 4, no. 3, pp. 218-225.

SHARMA, A. - JOHRI, B.N. - SHARMA, A.K. - GLICK, B.R. 2003. Plant growth-promoting bacterium Pseudomonas $s p$. strain GRP3 influences iron acquisition in mung bean (Vigna radiata L. Wilzeck ). In Soil Biology and Biochemistry, vol. 35, no. 7, pp. 887-894.

SHIRVANI, M. - NOURBAKHSH, F. 2010. Desferrioxamine-B adsorption to and iron dissolution from palygorskite and sepiolite. In Applied Clay Science, vol. 48, pp. 393.

SIMON, D. - LYTTON, B.M. - LZAC, D. - GLICKSTEIN, H. - JACQUELINE, L. - SHANZER, A. - CABANTCHIK, Z.L. 1993. Mode of action of iron (III) chelators as antimalarials. In Membrane Permeation Properties and Cytotoxic Activity Blood, vol. 81, no. 1, pp. 214-221.

STEPHAN, U.W. - SCHMIDKE, I.V. - STEPHAN, W. - SCHOLZ, G. 1996. The nicotianamine molecule is made-to-measure for complexation of metal micronutrients in plants. In Biometals, vol. 9, pp. 84-90.

STEPHEN, J. - LANE, P.S. - MARSHALL, R.J. - UPTON, C. 1998. Isolation and characterization of carboxy mycobactins as the second extracellular siderophores in Mycobacterium smegmatis. In Biometals, vol. 11 , no. 1 , pp. 13-20.

STINTZI, A. - BARNES, C. - XU, J. - KENNETH, N. 2000. Raymond microbial iron transport via a siderophore shuttle: A membrane ion transport paradigm. In PNAS (Proceedings of the National Academy of Science), vol. 97, no. 20, pp. 10691-10696, DOI:10.1073/pnas.200318797.

TAKAGI, S. 1976. Naturally occurring iron-chelating compounds in oat and rice-root washings: activity measurement and preliminary characterizations. In Soil Science and Plant Nutrition, vol. 22, pp. 423433.
THIEKEN, A. - WINKELMANN, G. 1992. Rhizoferrin: a complexone type siderophore of the Mucorales and entomophthorales (Zygomycetes). In Federation of European Biochemical Societies Microbiol Letters vol. 73, pp. 37-41.

VAN DER LELIE, D. - CORBISIER, P. - DIELS, L. 1999. The role of bacteria in the phytoremediation of heavy metals. In TERRY, N. - BANUELOS, E. (Eds) Phytoremediation of Contaminated Soil and Water. Lewis Publisher, USA. pp. 265-281. ISBN 1-56670$450-2$.

VANDENBERGH, P.A. - GONZALEZ, C.F. 1984. Method for protecting the growth of plants employing mutant siderophore producing strains of Pseudomonas putida, United States Patent Number: 4, 479, 936.

VANSUYT, G. - ROBIN, A. - BRIAT, J.F. - CURIE, C. - LEMANCEAU, P. 2007. Iron acquisition from Fe-pyoverdine by Arabidopsis thaliana. In Molecular Plant-Microbe Interactions, vol. 20, no. 4, pp. 441-447.

VARMA, A. - PODILA, G.K. 2005. Siderophore their biotechnological application. In Biotechnological Applications of Microbes, pp. 177-199.

VERMA, V.C. - SINGH, S.K. - PRAKASH, S. 2011. Bio-control and plant growth promotion potential of siderophore producing endophytic Streptomyces from Azadirachta indica A. Juss. In Journal of Basic Microbiology, vol. 51, pp. 550-556. DOI: 10.1002/ jobm.201000155.

VISCA, P. - CIERVO, A. - ORSI, N. 1994. Cloning and nucleotide sequence of the $p v d \mathrm{~A}$ gene encoding the pyoverdine biosynthetic enzyme L-ornithine N5-oxygenase in Pseudomonas aeruginosa. In Journal of Bacteriology, vol. 176, pp. 1128-1140.

VON GUNTEN, H.R. - BENES, P. 1995. Speciation of radionuclides in the environment. In Radiochimica Acta, vol. 69, pp. 1-29.

WALSH, C.T. - JUN, L. - RUSNAK, F. - SAKAITANI, M. 1990. Molecular studies on enzymes in chorismate metabolism and the enterobactin biosynthetic pathway. In Chemical Reviews, vol. 90, no. 7, pp. 1105-1129.

WANG, P. - MORI, T. - KOMORI, K. - SASATSU, M. - TODA, K. - OHTAKE, H. 1989. Isolation and characterization of an Enterobacter cloacae strain that reduces hexavalent chromium under anaerobic conditions. In Applied and Environmental Microbiology, vol. 55 , no. 7 , pp. $1665-1669$.

WANG, P. - MORI, T. - KOMORI, K. - SASATSU, M. - TODA, K. - OHTAKE, H. 1989. Isolation and characterization of an enterobacter cloacae strain that reduces hexavalent chromium under anaerobic conditions. In Applied and Environmental Microbiology, vol. 55, no. 7, pp. 1665-1669.

WANG, Q. - XIONG, D. - ZHAO, P. - YU, X. - TU, B. - WANG, G. 2011. Effect of applying an arsenic-resistant and plant growth-promoting rhizobacterium to enhance soil arsenic phytoremediation by Populus deltoides LH05-17. In Journal of Applied Microbiology, vol. 111, pp. 1065-1074. 
WARD, T.R. - REAS, L. - SERGE, P. - PAREL, J.E. - PHILIPP, G. - PETER, B. - CHRIS, O. 1999. An iron-based molecular redox switch as a model for iron release from enterobactin via the salicylate binding mode. In Inorganic Chemistry, vol. 38, no. 22, pp. 5007-5017.

WENDENBAUM, S. - DEMANGE, P. - DELL, A. MEYER, J.M. - ABDALLAH, M.A. 1983. The structure of pyoverdine $\mathrm{Pa}$, the siderophore of Pseudomonas aeruginosa. In Tetrahedron Letters, vol. 24, no. 44, pp. 4877-4880.

WHO Model List of Essential Medicines. World Health Organization. October, 2013. Retrieved 22 April 2014.

WINKELMANN, G. 1991. Specificity of iron transport in bacteria and fungi. In WINKELMANN, G. (Ed). Handbook of microbial iron chelates. Boca Raton : Fla: CRC Press. pp. 65-106.
WITTMANN, S. - HEINISCH, L. - SCHERLITZ -HOFMANN, I.N.A. - STOIBER, T. - DOROTHE, A.F. - MÖLlmANN, U. 2001. Catecholates and mixed catecholate hydroxamates as artificial siderophores for mycobacteria. In Biometals, vol. 17, pp. 53-64.

YADAV, S. - KAUSHIK, R. - SAXENA, A.K. - ARORA, D.K. 2011. Diversity and phylogeny of plant growth promoting bacilli from moderately acidic soil. In Journal of Basic Microbiology, vol. 51, pp. 98-106.

ZAHNER, H. - KELLER-SCHIERLEIN, W. - HÜTTER, R. - HESS-LESINGER, K. - DEER, A. 1963. Stoffwechselprodukte von Mikroorganismen. Sideramineaus Aspergillacaeen. In Archives of Microbiology, vol.45, vol. 119-135.

Received: May 22, 2015 